\title{
The Financial Impact of Revising Pakistan's Gasoline Specification from 87 to 92 Research Octane Number
}

\author{
MUHAMMAD FAHAD KHAN \\ Riphah International University \\ Email: tomeetfahad@gmail.com \\ Tel: +923002618234 \\ AWAIS REHMAN \\ Attock Refinery limited \\ Email: awaisrehman08@gmail.com \\ Tel: +923334188652 \\ Dr. NAWAR KHAN \\ Riphah International University \\ Email: nawar.khan@ riphah.edu.pk
}

\begin{abstract}
Petrol is a component having high energy of combustion. The product is produced from naphtha a raw material to produce gasoline, Industrial Technologies Program (2006). In terms of PSQCA (Pakistan standard of quality control authority) it is known as Premium (unleaded) Motor Gasoline (PMG). The product is use in electricity generators, two wheelers, three wheelers (auto rickshaw), motor cars and heavy vehicles all around the country. The vehicular contribution for consumption of petrol is analysed by analysts where they believe that "the share of motorbikes (two wheelers) in the overall consumption of petrol in the country is over 55 per cent", Aamir Shafaat Khan (2017). The specification for research octane number (RON) of gasoline was revised from 87 RON to 92 RON during financial year 2016-17. For being a major consumer of total gasoline sale, the study is carried out to find the economical impact of consuming 92 RON gasolines instead of 87 RON in two wheelers \& three wheelers.
\end{abstract}

Keywords: Petrol, Prices, Octane Number, Impact.

\section{Introduction}

The total observed consumption of petroleum products during financial year 2016-17 was recorded at 27 million tons with a rise of 9.64 percent compared to 2015-16. The gasoline consumption for the year 201617 reported was 6,646,965 metric tons (M.Tons) which was $15.4 \%$ higher than the consumption of year 2015-16 i.e.5,759,763 metric tons and 40.46\% higher than year 2014-15 i.e. 4,732,381 metric tons, OCAC (Oil Companies Advisory Committee), Pakistan Oil Report (2016-17).

During 2017 the octane specification for regular gasoline was revised from 87 to 92 RON by ECC (Economic Coordination Committee), Government of Pakistan. The crude oil refineries and oil marketing companies were restricted to produce and import $92 \mathrm{RON}$ gasoline respectively against ECC press release 1742, (August, 2016). The study is carried out to find out the financial impact of change of order and introduction of new product. The scope of the study is to calculate the financial impact of consuming 92 
RON gasoline in two wheelers and three wheelers, rather than consuming $87 \mathrm{RON}$, as they are major consumer of the product.

\section{Literature Review}

Gasoline is industrial name of product used in spark ignition engines (Seddon \& Ptyltd, 2000). It is the major product of crude oil refinery and is produced through different technologies installed countrywide i.e. Reforming and Isomerisation process, moreover, the raw material to produce gasoline is naphtha, Refinery flow diagram (DOE, 1998). Both these processes are use to enhance RON of gasoline. Reforming Process is known as the power house of RON enhancement it is used in almost all refineries to enhance RON of the raw material by 40 to 50 numbers. Similarly, Isomerisation process is used to raise the octane of product to maximum of 90 RON (Seddon \& Ptyltd, 2000). Octane number is the measured quality of a gasoline to resist knocking. The octane number of raw material to produce gasoline varies from 60 to 70 .

The final products of Reformer and Isomer are blended together to produce regular and premier motor gasoline. Moreover, every refinery has its own processes sequence based on requirement and economic evaluation (Gary et al., 2007). Some of the producers add the product obtained from both these units and blend with octane boosters or other high octane products to form a final blend of gasoline with wide range of octane number varying between 87 to over 100 RON (Octane Report, 2000). Two commercial grades of 87 and 89 RON were also reported to be used, (Li et al., 2012).

There is some added cost of producing higher RON petrol. Any added RON of gasoline costs in terms of money. Introduction of any change in octane needs substantial study and reviews before its implementation because the change would force reconfiguration of existing refinery operation subject to, if the process sequence and the existing installations allow. Otherwise new installations may also be required (Seddon \& Ptyltd, 2000). The reconfiguration of existing processes may affect the production capacity of other associated petroleum products.

Table-I, Top Ten Largest Markets of 2- and 3- Wheelers in Asia and their Growth. Data from World Road Statistics (WRS, 2010)

\begin{tabular}{|lcccccc|}
\hline \multicolumn{1}{|c}{ Country } & Year & $\begin{array}{c}\text { Vehicles } \\
\text { (No.) }\end{array}$ & $\begin{array}{c}\text { Motorcycles } \\
\text { \& Mopeds }\end{array}$ & $\begin{array}{c}\text { Motorcycles } \\
(\boldsymbol{\%})\end{array}$ & $\begin{array}{c}\text { Avg. Annual } \\
\text { growth (Other } \\
\text { Vehicles) }\end{array}$ & $\begin{array}{c}\text { Avg. Annual } \\
\text { growth } \\
\text { (motorcycles) }\end{array}$ \\
China & 2009 & $62,136,896$ & $95,805,176$ & $60.7 \%$ & $30.9 \%$ & $10.4 \%$ \\
India & 2009 & $21,200,140$ & $82,402,105$ & $79.5 \%$ & $10.7 \%$ & $12.1 \%$ \\
Indonesia & 2009 & $18,281,437$ & $52,433,132$ & $74.1 \%$ & $22.6 \%$ & $20.9 \%$ \\
Vietnam & 2007 & $1,146,312$ & $21,779,919$ & $95.0 \%$ & ND & ND \\
Thailand & 2006 & $8,923,447$ & $15,674,941$ & $63.7 \%$ & $6.8 \%$ & $2.6 \%$ \\
Taiwan & 2009 & $6,718,746$ & $14,604,330$ & $68.5 \%$ & $2.3 \%$ & $3.3 \%$ \\
Malaysia & 2008 & $9,030,292$ & $8,487,451$ & $48.5 \%$ & $7.1 \%$ & $7.5 \%$ \\
Pakistan & 2009 & $2,170,430$ & $3,383,493$ & $60.9 \%$ & $10.4 \%$ & $13.0 \%$ \\
Philippine & 2009 & $2,990,743$ & $3,200,968$ & $51.7 \%$ & $2.0 \%$ & $23.5 \%$ \\
Sri Lanka & 2009 & 951.362 & $2,339,916$ & $71.1 \%$ & ND & $8.0 \%$ \\
\hline
\end{tabular}

Octane boosters remained in use to cater the higher market demand of gasoline with improved octane number. Additives were opted by the countries having lower technology advancement to produce gasoline, (Ivanova \& Tsigankova, 2011). Most of the countries have adopted timely investment techniques on technology advancement for production of gasoline (Gasoline event report, 2012). Those countries where the industry does not provide sufficient production of high gasoline fractions are using octane boosters due to its extended commercial benefits and negligible environmental impacts (Tretjakov, 2013). These chemicals and additives have potential hazard due to which refineries should opt for technology advancement for production of high octane gasoline (Albahri et al., 2012). Whether it is by using additives 
\& chemicals or by technology advancement; each RON enhancement has its price to be paid at all levels i.e. from design to disposal and from producer to consumer.

Pakistan, for being a gasoline deficit country has a limited production facility of only 34 percent of its total consumption and is heavily dependent on imports of gasoline (Khan \& Khan, 2018). Moreover, around 55 percent of the total gasoline sale was consumed in two wheelers and three wheelers. The growth in sale of two wheelers and three wheelers for top ten largest markets of Asia is mentioned in Table-I

\begin{tabular}{|lccccc|}
\hline \multicolumn{5}{|c|}{ Table-II, Vehicles On Road In Pakistan (OCAC, 2016-17) } \\
\hline Vehicle Type & $2014-15$ & $2016-17$ & Difference & $\%$ difference & Annual \\
& & & & & Raise \\
Motor Cycle/ Scooter & $6,405,000$ & $6,962,100$ & 557,100 & 8.70 & 4.35 \\
Motor Rickshaws & 112,000 & 123,300 & 11,300 & 10.09 & 5.04 \\
\hline
\end{tabular}

The growth of such kind of vehicles in Pakistan is $13.0 \%$ for the specified duration Posada, et al (2011). The total number of two wheelers and three wheelers (Motor Rickshaws) on road during financial year 2014-15 was 6,405,000 and 112,000 respectively. The numbers recorded for the same vehicles during financial year 2016-17 were 6,962,100 and 123,300 respectively with total raise of 8.7 and 10.1 percent respectively as shown in Table-II.

Gasoline specification of 87 RON is sufficient to fulfill the requirement of South Asia, Kojima, et al (2000), yet a manufacturer manual could be a better guide about the actual requirement of a specific vehicle. The general octane grading is done in three distinguished categories i.e. "Regular (usually 87 octane), Mid-grade (usually 89 octane), and Premium (usually 92 or 93)", "Unless it's recommended by your owner's manual, don't spend the money on high octane gas. In most of the cases, there's no benefit. Higher octane helps only if you have problems with your engine knocking" (Federal Trade Commission, 2012).

High RON gasoline is used in engines having high compression ratio requirement. Where compression ratio is elaborated as "In a four cylinder, 2-liter engine, each cylinder would have a 500 cc capacity," says John Nielsen, director of approved auto repair with the American Automobile Association (AAA). "As the piston moves down the cylinder, it draws in $500 \mathrm{cc}$ of air and fuel. The valves close and the piston moves up, compressing the $500 \mathrm{cc}$ charge. If that charge is compressed into $50 \mathrm{cc}$, the compression ratio of the engine would be 10:1." According to AAA's Nielsen, "using a higher-octane fuel than your car requires won't hurt anything, but it also won't help and you'll be paying more for it, so it hurts in a different way".

The compression ratio of Honda CIVIC i-VTEC CVT is 9.7:1 and that of Toyota Altis Grande CVT-i 1.8 is 10.0:1. Similarly, both Honda Aspire 1.3 i-VTE with engine of 100 horse power (HP) and Toyota GLI 1.3 vvti with engine of $84 \mathrm{HP}$ has compression ratio of 10.5:1.

Thus the owner manual of both Honda Civic 1.8L and Toyota Corolla GLI showed that the required fuel for these vehicles is gasoline with 87 RON. Therefore, for heavy engines with designed compression ratio of 10.5:1 and engine capacity of up to $1,800 \mathrm{cc}$, the fuel of $87 \mathrm{RON}$ suffices the requirement. The compression ratio of 4 stroke single cylinder air cooled engines of two wheelers running on road of Pakistan are; 9.0:1 for Honda CG 125 having engine capacity of $125 \mathrm{cc}$ and for Suzuki GS 150 it is 9.2:1 having engine capacity of $150 \mathrm{cc}$.

\section{Data Analysis}

Pakistan is a gasoline deficit country and is dependent mostly on imports to fulfill its local demands. However a raise of 15.5 percent has observed over the period of two years i.e. from financial year 2014-15 to financial year 2016-17. The average annual raise observed was $7.75 \%$, as mentioned in Table-III. 


\begin{tabular}{|lccccc|}
\hline \multicolumn{5}{|c|}{ Table-III, Pakistan's Gasoline Production (OCAC, 2016-17) } \\
\hline PRODUCT & $2014-15$ & $2016-17$ & Difference & $\%$ difference & Annual raise \\
Gasoline (M.Tons) & $1,591,440$ & $1,838,190$ & 246,750 & 15.50 & 7.75 \\
\hline
\end{tabular}

Assessing the sales of gasoline in Table-IV, over these two years, 40.46 percent raise in consumption of gasoline has been observed. The total raise in consumption in terms of figures was around two million metric tons. The average annual increase in demand of gasoline remained 20.23 percent while rate of enhancement of local gasoline production observed at 7.75 percent (only) per year, that had worsen the country's problem of gasoline deficiency, generating more room for gasoline imports.

\begin{tabular}{|lccccc|}
\hline \multicolumn{5}{|c|}{ Table-IV, Pakistan's Gasoline Sales/Consumption (OCAC, 2016-17) } \\
\hline PRODUCT & $2014-15$ & $2016-17$ & Difference & $\%$ difference & Annual raise \\
Gasoline (M.Tons) & $4,732,381$ & $6,646,965$ & $1,914,584$ & 40.46 & 20.23 \\
\hline
\end{tabular}

As logged in Table-V, during financial year 2014-15 the deficit of gasoline production over its consumption was 3,140,941 M.Tons which was $197 \%$ of the local production. Observing the same data for financial year 2016-17 the deficit enhanced to 4,808,775 M.Tons which was $262 \%$ for the year. The in-house gasoline production over its consumption has risen by 64.24 percent over the period of two years. This deficiency was fulfilled by more imports. An average annual increase of 26.55 percent was observed in imports to cater the raise in demand of gasoline.

\begin{tabular}{|lcc|}
\hline \multicolumn{3}{|c|}{ Table-V, Gasoline Production Over Consumption (OCAC, 2016-17) } \\
\hline Details & $\mathbf{2 0 1 4 - 1 5}$ & $\mathbf{2 0 1 6 - 1 7}$ \\
\hline Production (M.Tons) & $1,591,440$ & $1,838,190$ \\
Consumption (M.Tons) & $4,732,381$ & $6,646,965$ \\
Deficit (M.Tons) & $3,140,941$ & $4,808,775$ \\
Deficit in local production Vs consumption (\%) & \multicolumn{2}{|c|}{64.24} \\
Annual Deficit & \multicolumn{2}{c|}{32.12} \\
Raise in gasoline Imports (\%) & \multicolumn{2}{|c|}{53.10} \\
Annual Raise & 26.55 \\
\hline
\end{tabular}

One of the key factors in high gasoline demand was the rise in number of vehicles on road. The total vehicles on road over these two years were raised by 17 percent. The major consumers of gasoline are cars, two wheelers, Auto rickshaws, passenger vehicles, Taxi etc. However, researchers believe that "the share of motorbikes (two wheelers) in the overall consumption of petrol in the country is over 55 percent" (Khan, 2017). Therefore, the two wheelers' and three wheelers' production or consumption has been assessed in Table-II. Whereas Table-VI shows the total gasoline consumed during financial year 2016-17 in these vehicles.

\begin{tabular}{|lcc|}
\hline \multicolumn{3}{|c|}{ Table-VI, Gasoline Consumed In Two/Three Wheelers 2016-17 } \\
\hline Details & MT & Liters \\
Total Gasoline consumed & $6,646,965$ & $9,033,225,435$ \\
Two Wheelers \& Auto Rickshaws & 55 & $\%$ \\
& $4,968,273,989$ & Liters \\
\hline
\end{tabular}

During financial year 2014-15, the country wise specification for octane number of regular gasoline was 87 RON (Research Octane Number) which was revised to 92 RON, ECC (2017). Most of the vehicles at the time of aforementioned changed order, including 55 percent of two wheelers and three wheelers, were 
designed to run on regular gasoline. Running extra octane in vehicle has no impact on engine performance but is waste of money and has negative impact both on consumer pocket and country economy. A sudden change in the octane specification to $92 \mathrm{RON}$ is non productive for these vehicles and even to the other old version vehicles running on the road.

Being a consumer we would never want to burn and pay for extra octane if the gasoline of desired low octane is available in the market. Calculated cost of one extra octane per liter is Rupees 0.86 per octane per liter (Rs/RON/L) for the year 2016-17 as mentioned in table-VII. Hence five extra octanes in a vehicle that is designed to run on $87 \mathrm{RON}$ has cost the consumer by 4.29 Rupees per liter. Although most of the vehicles on road during financial year 2016-17 were designed and run on 87 octane number normally yet in this paper we have targeted two wheelers and three wheelers on road only to calculate the extra payment made for octane and burdened the country's economy. Table-VIII, elaborated the extra payment made for total fuel consumed in two wheelers and three wheelers.

\begin{tabular}{|lccc|}
\hline \multicolumn{4}{|c|}{ Table- VII, Price of One Octane (Rupees) } \\
\hline Product & $\begin{array}{c}\text { Price 92 } \\
\text { RON* }\end{array}$ & $\begin{array}{c}\text { Price 87 } \\
\text { RON** }\end{array}$ & Rs/RON/L \\
Motor Spirit & 41.49 & 37.2 & 0.86 \\
$*$ Average Ex-Refinery price of Jan-June 17 & & \\
** Average Ex-Refinery price of July-16 June -17. & \\
PSO entitled import prices to Refineries. & & \\
\hline
\end{tabular}

Based on the fact that the share of motorbikes (two wheelers \& three wheelers) in the overall consumption of the country is around 55\%, (Khan, 2017), the total gasoline consumed during the year 2016-17 in these vehicles was 4,968,273,989 liters, Table-VI. The total ex- refinery price for the product remained 206.3 billion Pakistani Rupees having 92 octane numbers for the year 2016-17. Calculating back the same product with 87 RON the consumer has paid 21.31 billion over the year without getting any benefit out of it, costing the country in terms of economy and Rupee depreciation.

\begin{tabular}{|lcc|}
\hline \multicolumn{2}{|c|}{ Table-VIII , Extra Revenue Consumed Using } & 92 RON Gasoline (BILLIONS) \\
\hline Details & 87 RON & 92 RON \\
Two Wheelers \& Auto Rickshaws & 185 & 206.13 \\
Extra Revenue consumed & 21.31 & Rs \\
\hline
\end{tabular}

The major reason for its dependency on imports is the deficiency of local gasoline availability in Pakistan. The country has limited production facility and has deficit of around 64 percent against local production. On average, the import of gasoline raised by $26.5 \%$ from the year 2014-15 to 2016-17. Moreover, producing high octane gasoline requires more installation which needs huge investment and enough time to develop and commission which doesn't seems suitable for developing country like Pakistan (Khan \& Khan, 2018).

\section{Discussion}

Despite an average annual raise in local production of gasoline by 7.75 percent, the demand of gasoline has risen by 32 percent over its production capacity which created more room for imports. The change in octane specification has also played an added role in augmenting the gasoline deficits of country. The total gasoline consumed in two wheelers and three wheelers over the year was 4,968,273,989 liters. They along with other old vehicles on road were designed on 87 RON gasoline. The sudden change in gasoline specification has burdened the consumer pocket in terms of paying for extra octane. Over the span of one year, the consumer has paid Rupees 23.31 billion without getting any benefit out of it. 


\section{Conclusion}

The revised specification of $92 \mathrm{RON}$ for gasoline should be reviewed based on the type of vehicles on road and overall requirement of the country. The consumption of petrol in two wheelers and three wheelers has major contribution in gasoline market of Pakistan. They are designed and were running normal on 87 RON gasoline therefore the grade should be maintained in the market to avoid extra burden not only on consumer's pocket but also on the country's economy. It may also have positive impact on local gasoline production as well as reduction in imports of energy products. For consumer awareness, the retail outlet should also be restricted to mention the octane rating of fuel on the dispensers.

\section{References}

Albahri, T.A., Riazi, M.R. and Alqattan, A.A. (2002). Octane number and aniline point of petroleum fuels. Fuel Chemistry Division Preprints, 47(2), p.710.

Compression Ratio and Octane Ratings: What You Need to Know by Chris Warren.

ECC (Economic coordination committee, Ministry of Finance, Government of Pakistan) press release, August 18, 2016 (PR No. 1742).

Federal Trade Commission. "The Low-Down on High Octane Gasoline," brochure. Oct., 2003 (Dec. 15, 2011). http://www.ftc.gov/bcp/edu/pubs/consumer/autos/aut12.shtm

Gary, J. H., Handwerk, G. E., \& Kaiser, M. J. (2007). Petroleum refining: technology and economics. CRC press.

Gasoline event report. (2012) the international gasoline 2012 conference, organized by Creon energy.

https://cdn.dealereprocess.net/cdn/servicemanuals/honda/2017-civic.pdf

https://www.toyota.com/t3Portal/document/om-s/OM02494U/pdf/OM02494U.pdf

Ivanova, M.V. and Tsigankova, E.V., 2011. Benefits of additives using in oil-refining industry.

Khan, M. F., \& Khan, N. (2018). Indeginise Management Solution to Pakistan Excess Naphtha. GSJ, 6(12).

Kojima, M., Brandon, C., \& Shah, J. (2000). Improving urban air quality in South Asia by reducing emissions from two-stroke engine vehicles (No. 21911). Washington, D. C: World Bank.

Li, J., Tian, Z., Chen, Y., Cao, W., \& Zeng, Z. (2012). Distinguishing octane grades in gasoline using terahertz metamaterials. Applied optics, 51(16), 3258-3262.

Nielsen, John. Director of Approved Auto Repair at AAA. Personal correspondence. Dec. 16, 2011.

Oil companies advisory committee (OCAC), Oil Report 2014-15 \& Oil Report 2016-17

Petrol sales hit all-time high in Pakistan, Aamir Shafaat Khan, 2017, published in Dawn, September $23 r d, 2017$

Posada, F., Kamakate, F., \& Bandivadekar, A. (2011). Sustainable management of two-and three-wheelers in Asia. International Council on Clean Transportation, 953-957.

Seddon, D., \& Ptyltd, A. (2000). Octane Enhancing Petrol Additives. Products, Duncan Seddon \& Associates PTY Ltd.

The Industrial Technologies Program, Energy Bandwidth for Petroleum Refining Processes, 2006.

Tretjakov, A.E., 2013. Benefits Of Additives Using In Oil-Refining Industry.

U.S. Department of Energy (DOE), 1998, Energy and Environmental Profile of the U.S. Petroleum Refining Industry, DOE, Office of Energy Efficiency and Renewable Energy, Office of Industrial Technologies. 